\title{
Therapeutic Potential and Anti-Amyloidosis Mechanisms of Tert-Butylhydroquinone for Alzheimer's Disease
}

\author{
Hasina Akhter ${ }^{\mathrm{a}}$, Ashwini Katre ${ }^{\mathrm{a}}$, Ling Li ${ }^{\mathrm{b}}$, Xuebo Liu ${ }^{\mathrm{c}}$ and Rui-Ming Liu ${ }^{\mathrm{a}, *}$ \\ ${ }^{a}$ Department of Environmental Health Sciences, School of Public Health, University of Alabama at Birmingham, \\ Birmingham, AL, USA \\ ${ }^{\mathrm{b}}$ Department of Experimental and Clinical Pharmacology, College of Pharmacy, University of Minnesota, \\ $M N, U S A$ \\ ${ }^{\mathrm{c}}$ College of Food Science and Engineering, Northwest A\&F University, Shaanxi, China
}

Handling Associate Editor: D. Allan Butterfield

Accepted 16 May 2011

\begin{abstract}
Alzheimer's disease (AD) is a major cause of dementia in the elderly with no effective treatment. Accumulation of amyloid- $\beta$ peptide $(A \beta)$ in the brain, one of the pathological features of $A D$, is considered to be a central disease-causing and disease-promoting event in AD. In this study, we showed that feeding male A $\beta P P / P S 1$ transgenic mice, a well established mouse model of $\mathrm{AD}$, with a diet containing phenolic antioxidant tert-butylhydroquinone (TBHQ) dramatically reduced brain A $\beta$ load with no significant effect on the amounts of alpha- and beta-C-terminal fragments or full-length A $\beta P P$. Further studies showed that TBHQ diet inhibited the expression of plasminogen activator inhibitor-1 (PAI-1), a protease inhibitor which plays a critical role in brain $\mathrm{A} \beta$ accumulation in $\mathrm{AD}$, accompanied by increases in the activities of tissue type and urokinase type plasminogen activators (tPA and uPA) as well as plasmin. Moreover, we showed that TBHQ diet increased the expression of low density lipoprotein related protein-1, a multi ligand endocytotic receptor involved in transporting $A \beta$ out of the brain, and plasma $A \beta_{40}$ and $A \beta_{42}$ levels. We also showed that TBHQ diet increased the concentration of glutathione, an important antioxidant, and suppressed the expression of NADPH oxidase 2 as well as lipid peroxidation. Collectively, our data suggest that TBHQ may have therapeutic potential for $\mathrm{AD}$ by increasing brain antioxidant capacity/reducing oxidative stress level and by stimulating $\mathrm{A} \beta$ degradation/clearance pathways.
\end{abstract}

Keywords: Alzheimer's disease, amyloid- $\beta$ degradation, amyloid- $\beta$ efflux, antioxidant

\section{INTRODUCTION}

Alzheimer's disease (AD), a major course of dementia in the elderly, is a progressive neurodegenerative disease that gradually damages the neocortex and hippocampus. Despite extensive studies, there is no

\footnotetext{
*Correspondence to: R-M. Liu, Department of Environmental Health Sciences, School of Public Health, University of Alabama at Birmingham, Birmingham, AL 35294, USA. Tel.: (205) 934 7028; Fax: (205) 975 6341; E-mail: rliu@uab.edu.
}

effective treatment for this devastating disease due to an incomplete understanding of the etiology and pathophysiology of the disease. Formation of extracellular senile plaques, which are abnormal aggregates of amyloid- $\beta$ peptide $(A \beta)$, is a pathological feature of AD. Accumulation of both soluble and insoluble $A \beta$ in the brain has been suggested to be a disease-causing and disease-promoting event in AD. Consequently, developing the strategies to reduce brain $A \beta$ levels has been a focus of many studies including several 
clinical trials. Nonetheless, although several studies have shown that reduction of brain $\mathrm{A} \beta$ burden is associated with improvement of learning/memory function in animals and in AD patients [1-5], no drugs have been developed yet due to potential safety concerns or adverse effects.

$A \beta$ production is increased in early-onset (familial) $\mathrm{AD}$ due to mutations in the amyloid- $\beta$ protein precursor $(\mathrm{A} \beta \mathrm{PP})$ gene or the presenilin 1 and presenilin 2 (PS1 and PS2) genes. However, the mechanism underlying increased $A \beta$ accumulation in the brain of late-onset (sporadic) AD, which account for $95 \%$ of the cases, remains largely unknown. The brain is a site with high metabolic activity, high concentrations of prooxidants such as iron, and low antioxidant capacity, and therefore is highly sensitive to oxidative damage. It has been well documented that oxidative stress increases with age and in AD. It has also been shown that oxidative stress contributes importantly to $\mathrm{AD}$ pathology including neuronal cell death and $\mathrm{A} \beta$ accumulation while antioxidants, including lipoic acid and $\mathrm{N}$-acetylcysteine (NAC), reduce brain $\mathrm{A} \beta$ burden and/or improve cognitive function in animal models of $\mathrm{AD}$ [6-9]. These observations suggest therapeutic potential of antioxidants for the treatment of AD.

The phenolic compound tert-butyl hydroquinone (TBHQ) is a highly effective preservative used in a wide range of food and cosmetic products at the concentrations as high as $1 \% \mathrm{w} / \mathrm{w}$ with relative low toxicity (WHO Food Additives Series 4). In addition to directly scavenging free radicals [10], studies from this and other labs have shown that TBHQ increases the expression of the enzymes involved in the synthesis of glutathione (GSH), the most abundant intracellular free thiol and an important antioxidant, in various types of cells and in animal models [11-15]. TBHQ has also been shown to induce the expression of several other enzymes involved in detoxification and antioxidant defense through activation of nuclear factor erythroid 2-related factor 2 (Nrf2), a transcription factor controlling a pleiotropic cellular defense [14, 16, 17]. Most importantly, it has been reported that TBHQ protects neurons from oxidative damage induced by different toxicants or ischemia-reperfusion in vitro and in vivo $[14,15,18-23]$. Whether TBHQ can ameliorate pathological changes in $\mathrm{AD}$, a disease with many pathological features of oxidative stress, however, has not been reported.

In this study, we explored the therapeutic potential of TBHQ for $\mathrm{AD}$ using $\mathrm{A} \beta \mathrm{PP} / \mathrm{PS} 1$ mice, a well-established animal model of AD. Our results showed that feeding A $\beta P P / P S 1$ mice with TBHQ- containing diet significantly reduced brain $\mathrm{A} \beta$ load. Further studies suggest that TBHQ does so probably by increasing antioxidant capacity/reducing oxidative stress and stimulating $A \beta$ degradation and/or efflux from the brain. The results from this study suggest that TBHQ may have therapeutic value for AD.

\section{MATERIALS AND METHODS}

\section{Animals and TBHQ feeding}

A $\beta P P / P S 1$ double transgenic mice, purchased from JAXMICE, were generated by co-injection of human A $\beta P P$ and PS1 transgene constructs containing AD mutations (a mutant human presenilin 1 (DeltaE9) and a chimeric mouse/human amyloid- $\beta$ protein precursor) and were maintained on a C57BL/6 genetic background. Two and a half month old male A $\beta P P / P S 1$ mice were fed with either a control diet or $1 \%$ TBHQ-containing diet for 6 weeks. All the mice were maintained on a 12 -h light/dark cycle at $22^{\circ} \mathrm{C}$ with free access to water and food. Body weight and food intake were recorded weekly in order to monitor potential toxicity of TBHQ. By the end of feeding, mice were euthanized and blood withdrawn from the heart, followed by transcardial perfusion with cold PBS as we have described before [24]. Brain was dissected sagittally into right and left hemispheres with the right hemisphere fixed in 10\% PBS buffered formalin for immunostaining analysis and the left hemisphere dissected and hippocampus and cerebral cortex frozen in liquid nitrogen immediately for biochemistry analyses. All procedures involving animals were approved by the Institutional Animal Care and Use Committee at the University of Alabama at Birmingham.

\section{ELISA analyses of $A \beta$ and PAI-1 proteins in the brain}

For the measurement of soluble and insoluble $\mathrm{A} \beta$, mouse brain tissues were prepared as we have described previously [24]. Briefly, the brain tissues were homogenized in a $\mathrm{A} \beta$ extraction buffer containing $20 \mathrm{mM}$ Tris- $\mathrm{HCl}$ (pH 7.6), $137 \mathrm{mM} \mathrm{NaCl}, 1 \%$ Triton $\mathrm{X}-100,2 \%$ SDS, and protease inhibitors (complete protease inhibitor cocktail, Boehringer Mannheim, Mannheim, Germany), and centrifuged at 100,000 $\times g$ for $1 \mathrm{~h}$. Supernatant was collected (SDS soluble) and stored at $-80^{\circ} \mathrm{C}$ until analysis. Pellets were dissolved in $70 \%$ formic acid (FA), gentle shaking at room temperature for $1 \mathrm{~h}$, and then centrifuged at $100,000 \times g$ for $1 \mathrm{~h}$. The supernatants were collected 
(SDS insoluble/FA soluble). ELISA was performed to quantify SDS soluble and SDS insoluble/FA soluble $A \beta$ using the $A \beta_{40}$ or $A \beta_{42}$ ELISA kits from Covance (Emeryville, CA) [24]. The FA extraction solution was neutralized and diluted 20 times with a neutralizing buffer containing $1 \mathrm{M}$ Tris, $0.5 \mathrm{M} \mathrm{Na}_{2} \mathrm{HPO}_{4}$, and $0.05 \% \mathrm{NaN}_{3}$ before analysis by ELISA. For the measurement of PAI-1 protein in the brain, tissues were homogenized in Tris-HCl buffer containing $0.1 \%$ Triton-X 100, $\mathrm{pH}$ 8.5. After ultracentrifugation at $100,000 \times g$ for $1 \mathrm{~h}$, the supernatants were used for the measurement of total PAI-1 protein levels using an ELISA kit as we have described before [26]. The results were calculated based on the standard curves and expressed as per protein concentrations.

\section{Immunohistochemical staining of $A \beta$ deposits and low density lipoprotein related protein-1 (LRP-1) expression in mouse brain}

Immunohistochemical staining of $A \beta$ deposits in the brain was conducted using monoclonal anti-human $A \beta$ antibody 6E10 (Covance, Emeryville, CA) as previously described [24]. The amyloid load in the cerebral cortex and hippocampus was quantified by determining the percentage of the total section positively labeled by $\mathrm{A} \beta$ antibody using Axiovision automatic measurement software (Zeiss, Germany). For detection of the expression of LRP-1 protein in brain microvessels anti mouse LRP-1 light chain monoclonal antibody (5A6, Calbiochem) was used. The number of positive vessels was counted in five fields within cerebral cortex per mouse and the results were expressed as percentage of total number of blood vessels in the same area of the brain [25].

\section{Western analysis}

Mouse brain tissues were homogenized in a tissue extraction buffer containing 2\% SDS and different protease inhibitors as described above. Western analyses of full-length A $\beta P P$ and alpha/beta C-terminal fragments $(\alpha-/ \beta-C T F s)$ were performed using $4-20 \%$ gradient gel (Invitrogen). Full-length A $\beta P P$ proteins were detected with $6 \mathrm{E} 10$ antibody (Covance, Emeryville, CA) while $\alpha$ - and $\beta$-CTFs were determined using rabbit polyclonal antibody CT695 against the $\mathrm{C}$ terminus of AßPP (Invitrogen). LRP-1 protein was detected using anti mouse LRP-1 light chain monoclonal antibody (5A6) while the protein of NADPH oxidase 2 (Nox2), an important producer of reactive oxygen species (ROS), was detected with a polyclonal antibody (Santa Cruz, SC5827). Semi-quantification of the bands was performed by densitometric scanning using Image J software and normalized by $\beta$-actin. For detection of 4-hydroxy-2-nonenal (4-HNE) modified proteins, the brain tissues were homogenized and westerns run using non-reducing buffers. 4-HNE modified proteins were revealed by anti-4-HNE antibody (alpha Diagnostic, HNE-11 S).

\section{Zymographic analysis of the activities of tissue type and urokinase type plasminogen activators}

The activities of tissue type and urokinase type plasminogen activators (tPA and UPA, respectively) in mouse brain tissue were determined by zymographic analysis according to our previously described protocol $[24,26]$. Briefly, equal amounts of proteins were loaded onto $12 \%$ SDS polyacrylamide gel containing $1 \%$ nonfat dry milk and $5 \mu \mathrm{g} / \mathrm{ml}$ plasminogen. After electrophoresis, the enzyme reactions were initiated by incubating the gel in $0.1 \mathrm{M}$ glycine- $\mathrm{NaOH}$ ( $\mathrm{pH}$ 8.3) at $37^{\circ} \mathrm{C}$ for $16 \mathrm{~h}$. The lytic bands (tPA and uPA activity) were revealed by Coomassie blue staining and quantified using Image J system. Gels without plasminogen were also run simultaneously to ensure that the lytic bands are due to plasminogen activators. The tPA and uPA bands were identified based on both molecular weight and the loss of lytic activity upon inclusion of the plasmin inhibitor aprotinin $(2 \mu \mathrm{g} / \mathrm{ml})$.

\section{Measurement of plasmin activity in brain tissue}

Plasmin activities were measured using a specific chromogenic substrate Tosyl-glycyl-prolyl-lysine-4nitranilide-acetate (Chromzyme PL, from Roche Applied Sciences) as described before [24]. The reaction mixture contained $33 \mathrm{mM}$ Tris ( $\mathrm{pH} 8.2$ ), $6.4 \mathrm{mM} \mathrm{NaCl}$, and $0.5 \mathrm{mM}$ Chromozym PL. The timedependent production of 4-nitraniline was followed by monitoring the absorbance at $405 \mathrm{~nm}$. Plasmin activity was calculated using the 4-nitraniline extinction coefficient $\left(\varepsilon_{405 \mathrm{~nm}}=1 \times 10^{4} \mathrm{M}^{-1} \mathrm{~cm}^{-1}\right)$ and expressed as unites per protein concentration.

\section{Measurement of glutathione content in brain tissue}

Brain tissues were sonicated in 5\% sulfosalicylic acid and centrifuged. GSH concentrations in the supernatant were measured by a redox cycle assay as described before [27]. The protein content was measured by a BCA kit and GSH concentrations were calculated based on standard curve run together with 
the samples. The results were expressed as nmol/mg protein.

\section{Statistical analysis}

Data were expressed as mean \pm SEM and evaluated by one-way ANOVA. Statistical significance was determined by Fisher LSD test wherein $p<0.05$ were considered statistically significant.

\section{RESULTS}

\section{TBHQ diet caused no obvious toxicities in} A $\beta P P / P S 1$ mice

Two and a half month old male A $\beta P P / P S 1$ mice were fed with a diet containing $1 \%$ TBHQ for 6 weeks. The body weight and food intake were monitored during TBHQ feeding. No significant changes in body weight or food intake were observed in TBHQ fed mice as compared with control diet fed mice (data not shown). There was also no significant difference in the mortalities between TBHQ diet and control diet fed mice (data not shown). The results indicate that TBHQ, under the current feeding conditions, causes no significant toxicity.

\section{Effects of TBHQ diet on brain $A \beta$ load in A $\beta P P / P S 1$ mice}

$A \beta$ load in the brain was analyzed by immunohistochemical staining and ELISA techniques. Immunohistochemical staining showed that TBHQ feeding significantly reduced the numbers of senile plaque deposits in cerebral cortex/hippocampal region in AßPP/PS1 mice as compared to control diet fed mice (Fig. 1A, B). ELISA data further showed that TBHQ feeding significantly reduced the levels of both SDS
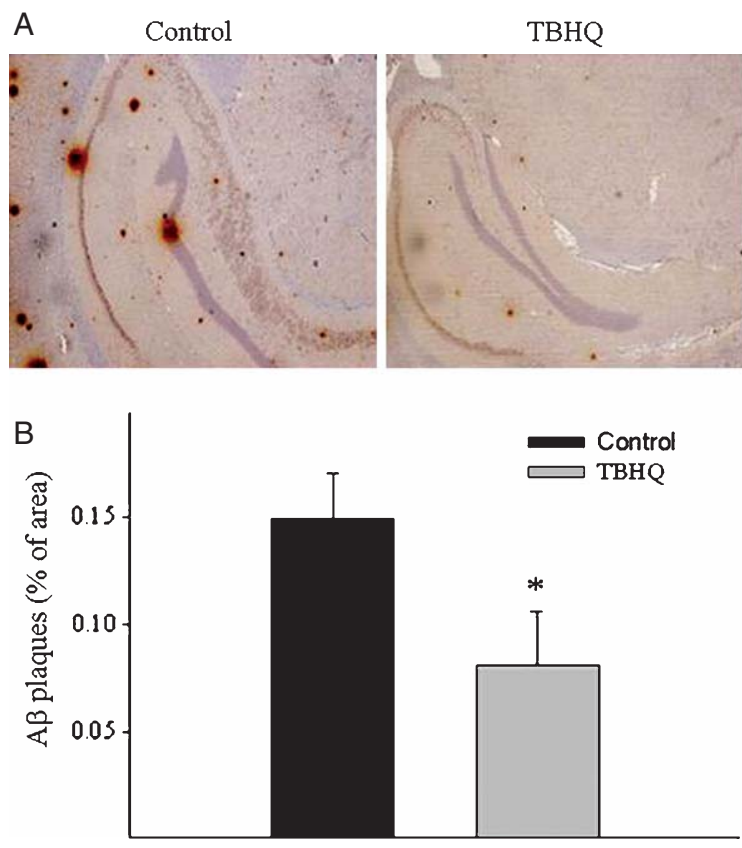

C
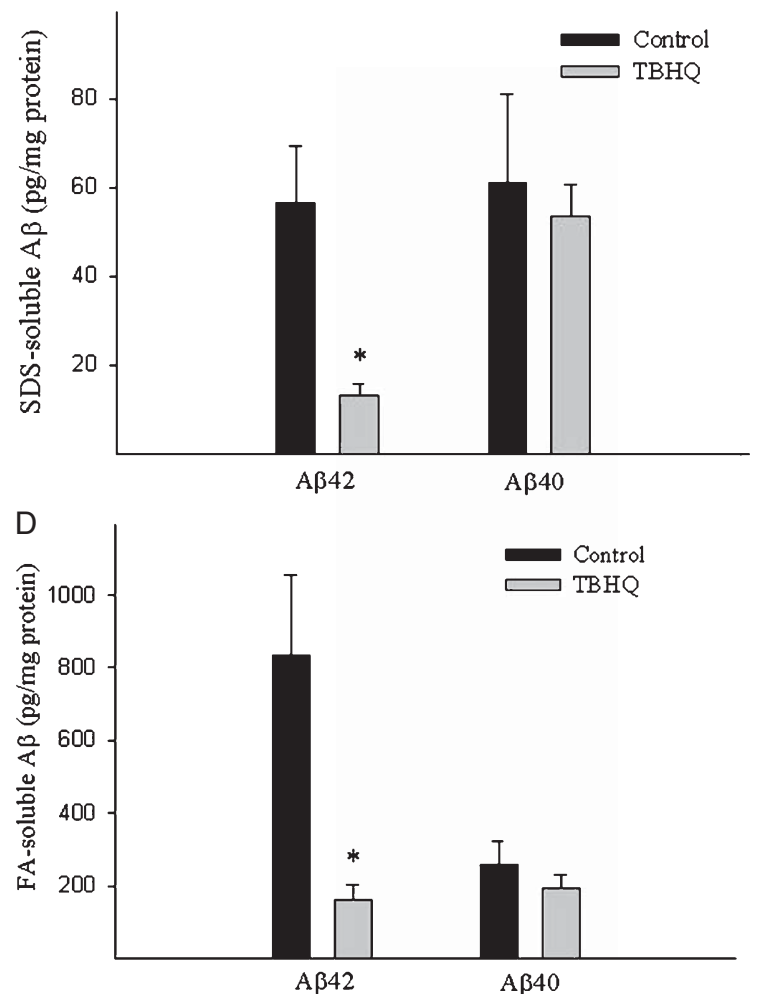

Fig. 1. Effect of TBHQ diet on A $\beta$ load in the brain of A $\beta P P / P S 1$ mice. Two and a half month old male A $\beta P P / P S 1$ mice were fed with TBHQ or control diet for 6 weeks. A $\beta$ deposits in the brain were revealed by immunohistochemical staining using antibody specific to human $A \beta$ (6E10) (A) and quantified by the histomorphometry system and expressed as percentage of total area of brain (B). The amounts of $A \beta_{40}$ and $A \beta_{42}$, both soluble and insoluble, in the brain were determined by ELISA and calculated based on the total protein content (C\&D). *Significantly different from the corresponding control diet fed mice $(p<0.05, n=5-7)$. 


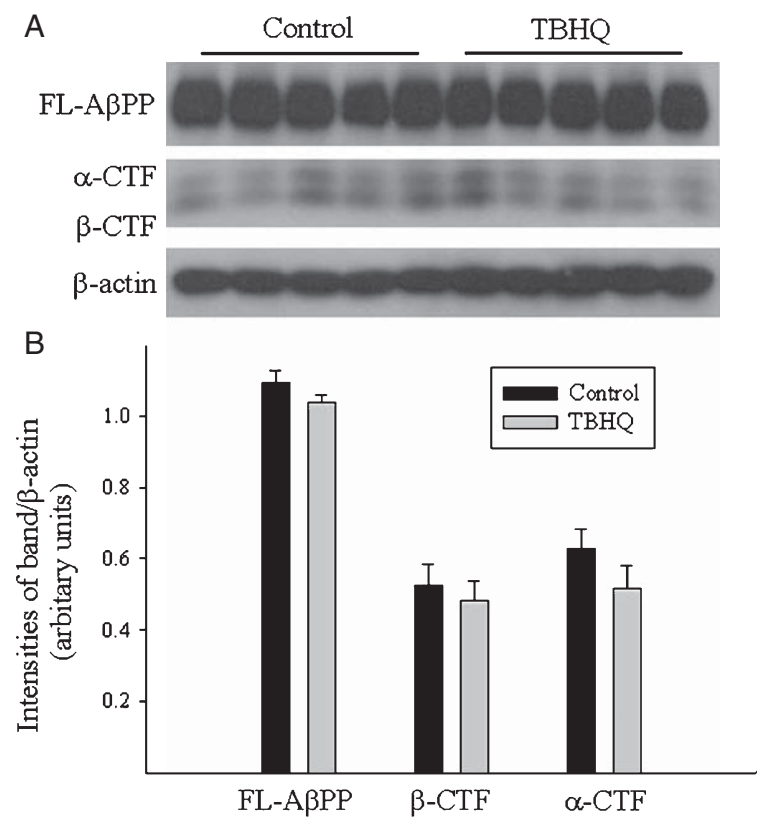

Fig. 2. Effects of TBHQ diet on the amounts of full-length A $\beta P P$, $\alpha-\mathrm{CTF}$, and $\beta-\mathrm{CTF}$ in the brain of A $\beta$ PP/PS1 mice. Full-length $\mathrm{A} \beta \mathrm{PP}(\mathrm{FL}-\mathrm{A} \beta \mathrm{PP})$ and $\alpha / \beta-\mathrm{CTF}$ in the brain of A $\beta P P / P S 1$ mice were determined by western analyses using $4-20 \%$ gradient SDSPAGE and anti-human $A \beta$ antibody (6E10) or $C$ terminus of human AßPP (CT695) (top panel). The intensities of the bands were semiquantified by densitometric scanning and normalized by $\beta$-actin (bottom panel). *Significantly different from control diet fed mice $(p<0.05, n=3-5)$.

soluble and insoluble $A \beta_{42}$ but had no significant effect on $A \beta_{40}$ levels (Fig. 1C, D). No $A \beta$ accumulation was detected in A $\beta P P / P S 1$ non-transgenic mice with or without TBHQ treatment (data not shown).

\section{Effects of TBHQ diet on the expression of full} length $A \beta P P, \alpha-C T F$, and $\beta-C T F$ in the brain of A $\beta P P / P S 1$ mice

To explore the mechanism whereby TBHQ reduced brain $A \beta$ load in $A \beta P P / P S 1$ mice, we measured the levels of full-length A $\beta P P$ (FL-A $\beta P P), \alpha-C$ terminal fragments $(\alpha-\mathrm{CTF})$ and $\beta-\mathrm{C}$ terminal fragments $(\beta-\mathrm{CTF})$ in the brain by Western blot. As shown in Fig. 2, there were no significant differences in the amounts of FL-A $\beta P P(\sim 100 \mathrm{kDa}), \alpha-\mathrm{CTF}$, or $\beta-\mathrm{CTF}$ between control diet and TBHQ diet fed mice. These results suggest that TBHQ diet reduces $A \beta$ load in the brain of $\mathrm{A} \beta \mathrm{PP} / \mathrm{PS} 1$ mice not by altering $\mathrm{A} \beta \mathrm{PP}$ expression/processing or inhibiting $A \beta$ production but by stimulating $A \beta$ degradation and/or efflux from the brain.
Effects of TBHQ diet on the expression of plasminogen activator inhibitor 1 and the activities of plasminogen activators as well as plasmin in the brain of $A \beta P P / P S 1$ mice

Plasminogen activator inhibitor 1 (PAI-1) is a primary inhibitor of tissue type and urokinase type plasminogen activator (tPA and uPA), which convert plasminogen into plasmin, a serine protease that plays a critical role in $A \beta$ degradation [28-32]. Our previous studies have shown that PAI-1 expression is increased in the brain of AD patients as well as in animal models of AD; knockout of the PAI-1 gene, on the other hand, reduced brain $A \beta$ burden in A $\beta P P / P S 1$ transgenic mice [24], suggesting a critical role of PAI-1 in brain $A \beta$ accumulation. To further elucidate the mechanism whereby TBHQ reduced brain A $\beta$ load in $\mathrm{A} \beta \mathrm{PP} / \mathrm{PS} 1$ mice, we compared PAI-1 protein levels as well as tPA, UPA, and plasmin activities between control diet and TBHQ diet fed mice. ELISA results showed that TBHQ diet significantly reduced PAI-1 protein levels in the brain of A $\beta$ PP/PS1 mice (Fig. 3A). Associated with inhibition of PAI-1 expression, TBHQ diet increased the activities of tPA and UPA as well as plasmin (Fig. 3B, C and D).

Effects of TBHQ diet on the expression of low density lipoprotein receptor related protein 1 in the blood-brain barrier and the levels of $A \beta$ in the plasma

LRP-1, a multi-function endocytic receptor expressed on endothelium of the blood-brain barrier (BBB), plays a major role in transporting $A \beta$ out of the brain (efflux) [33-36]. It has been reported that LRP-1 expression in the brain is decreased during aging and in $\mathrm{AD}$, associated with decreased $\mathrm{A} \beta$ efflux from and increased $A \beta$ accumulation in the brain [25, 37]. Therefore, we examined whether TBHQ diet reduced brain $A \beta$ load by increasing the expression of LRP-1 at the BBB. Immunohistochemical staining results showed that feeding mice with TBHQ diet significantly increased the abundance of LRP-1 protein at the $\mathrm{BBB}$ in $\mathrm{A} \beta \mathrm{PP} / \mathrm{PS} 1$ mice (Fig. 4A, B). Western analyses further confirmed that LRP-1 protein levels were increased in the brain of TBHQ fed A $\beta P P / P S 1$ mice as compared with control diet fed A $\beta P P / P S 1$ mice (Fig. 4C, D).

To further reveal whether increased LRP-1 expression was accompanied by an increase in $A \beta$ efflux from the brain, we measured $A \beta_{40}$ and $A \beta_{42}$ levels in the plasma of A $\beta P P / P S 1$ mice fed with control or TBHQ 


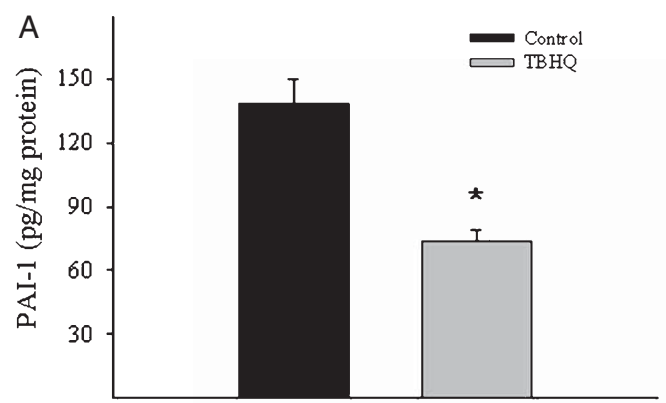

B
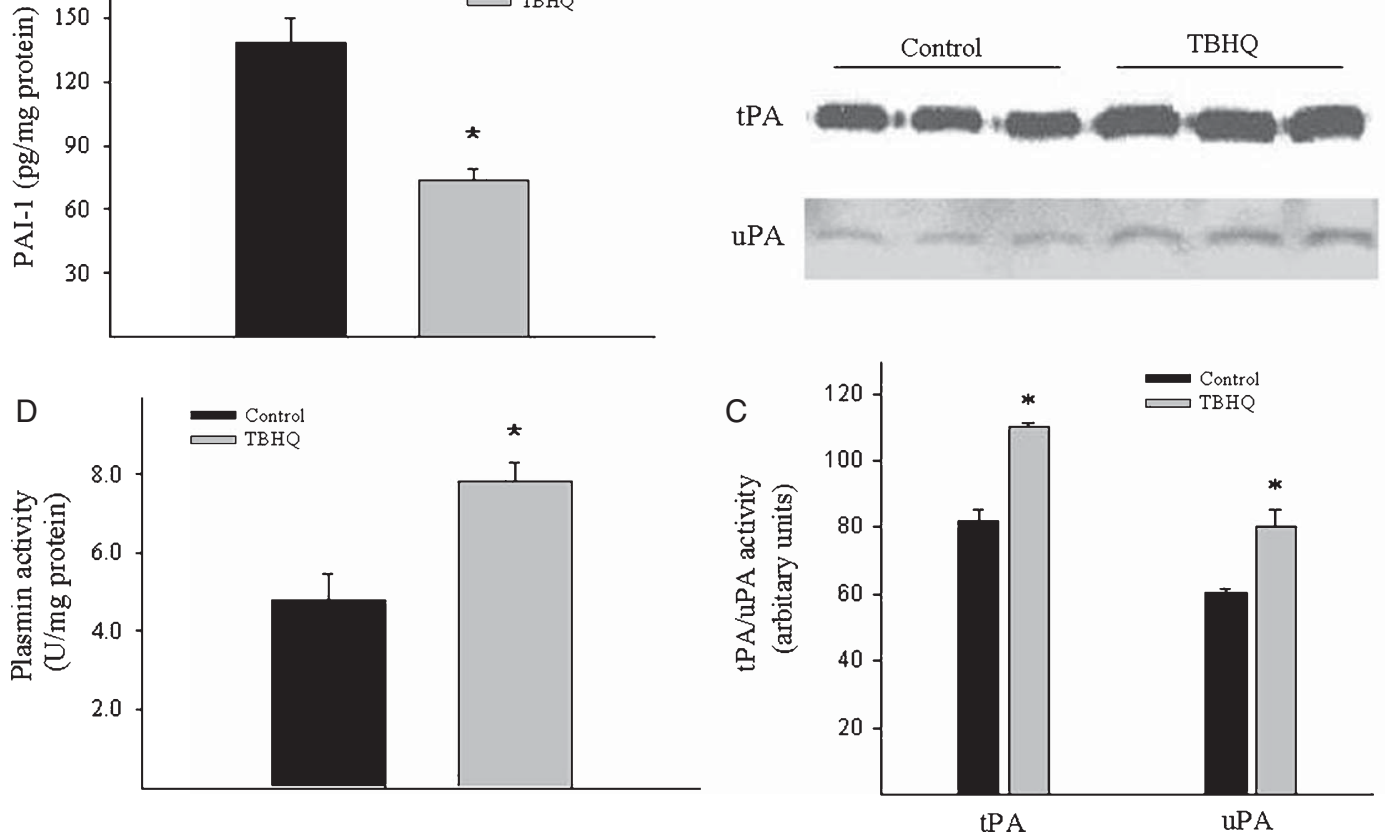

Fig. 3. Effects of TBHQ diet on PAI-1 protein expression and the activities of tPA, uPA, and plasmin in the brain of AßPP/PS1 mice. (A) PAI-1 protein levels in the brain tissue were determined by ELISA. (B) The activities of IPA and uPA in brain tissue were determined by zymography. (C) the intensities of the bands semi-quantified by densitometric scanning using Image $\mathbf{J}$ software. (D) Plasmin activity was determined using a specific chromogenic substrate as described in the Materials and Methods section. *Significantly different from control mice $(p<0.05, n=5-6)$.

diet. The results showed that TBHQ diet increased both $A \beta_{40}$ and $A \beta_{42}$ levels in the plasma of $A \beta P P / P S 1$ mice (Fig. 5).

Effects of TBHQ on glutathione content, NADPH oxidase 2 expression, and lipid peroxidation level in the brain of $A \beta P P / P S 1$ mice

Although it has been reported that TBHQ increases brain antioxidant capacity including the concentration of GSH, the most abundant intracellular free thiol and an important antioxidant, whether TBHQ can alleviate oxidative stress in $\mathrm{AD}$ is unknown. NADPH oxidases (Noxs) are important producers of ROS for both phagocytic and non-phagocytic cells while Nox2 is the prototype of NADPH oxidase family. To elucidate whether TBHQ diet can ameliorate oxidative stress levels in AD, we assessed the effects of TBHQ diet on the levels of Nox 2 protein, GSH, and lipid peroxidation (4-HNE) in the brain of A $\beta P P / P S 1$ mice. The results showed that TBHQ diet inhibited Nox2 protein expression (Fig. 6A,B), increased GSH level (Fig. 6C), and suppressed lipid peroxidation (Fig. 6D) in the brain of A $\beta P P / P S 1$ mice.

\section{DISCUSSION}

$\mathrm{AD}$ is a devastating neurodegenerative disease that affects about 27 million people worldwide [38]. Despite extensive study, the etiology of AD is still unclear and there is no effective treatment for this devastating disease. In this study, we showed that feeding 2.5 month old male A $\beta P P / P S 1$ mice with a diet containing a synthetic phenolic antioxidant TBHQ, which is widely used in food and cosmetic products as a preservative, for 6 weeks dramatically reduced their brain $A \beta$ load. Further studies suggest that TBHQ reduces brain $A \beta$ level probably by 1) suppressing PAI-1 expression/activity and thereby increasing the activities of tPA/uPA and plasmin and $\mathrm{A} \beta$ degradation; and 2) increasing LRP-1 expression at the BBB and thereby $A \beta$ efflux from the brain. We also showed that TBHQ increased GSH content and suppressed Nox2 expression as well as lipid peroxidation in the brain of A $\beta P P / P S 1$ mice. Therefore, it is speculated that TBHQ reduces brain oxidative stress levels in A $\beta P P / P S 1$ mice, which leads to suppression of PAI-1 but induction of LRP-1 expression and consequently stimulation of $A \beta$ degradation and efflux from the brain (Fig. 7). 

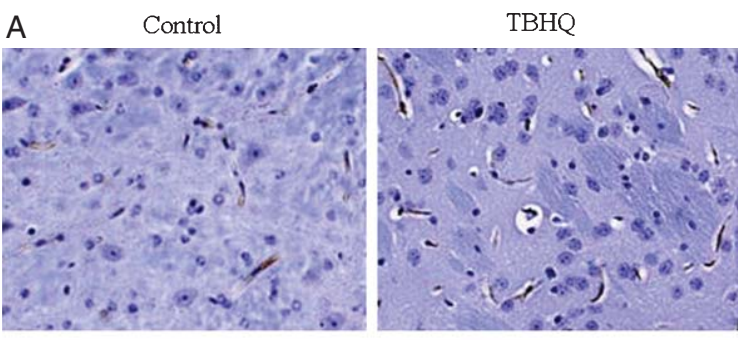

B

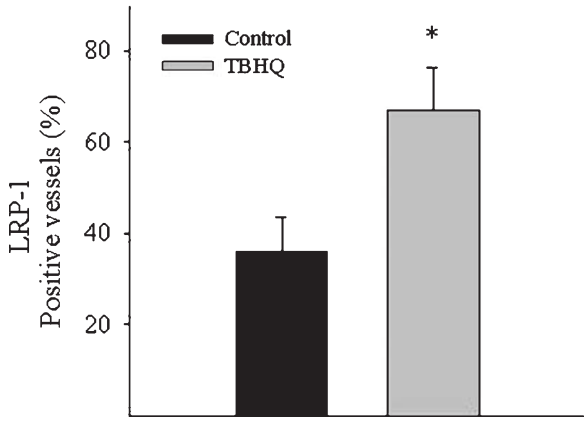

C

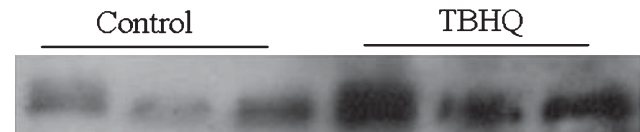

LRP-1

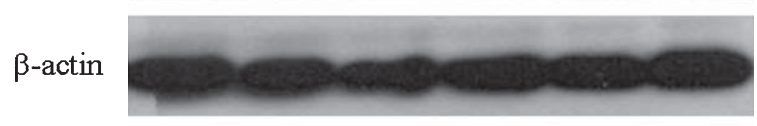

D

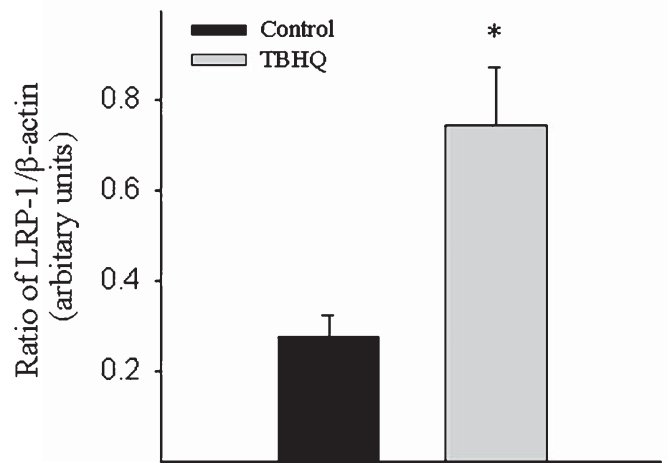

Fig. 4. Effects of TBHQ diet on the expression of LRP-1 at the BBB in $\mathrm{A} \beta \mathrm{PP} / \mathrm{PS} 1$ mice. A) Representative immunostaining pictures of LRP-1 protein in the brains of control-diet and TBHQ-diet fed mice. B) Quantification of LRP-1 positive blood vessels in cerebral cortex/hippocampus, expressed as percentage of total number of blood vessels in the same area of the brain. C) Representative western blotting picture of LRP-1 protein in cerebral cortex and hippocampus of A PPP/PS1 mice. D) Semi-quantitative data of western blotting. $*$ Significantly different from control diet fed $\mathrm{A} \beta \mathrm{PP} / \mathrm{PS} 1$ transgenic mice $(p<0.05, n=5)$.

Although it has been well documented that $A \beta$ production is increased in familial $\mathrm{AD}$ due to mutations in the A $\beta P P$ or PS1 and PS2 genes, the mechanism underlying $A \beta$ accumulation in the brain of sporadic

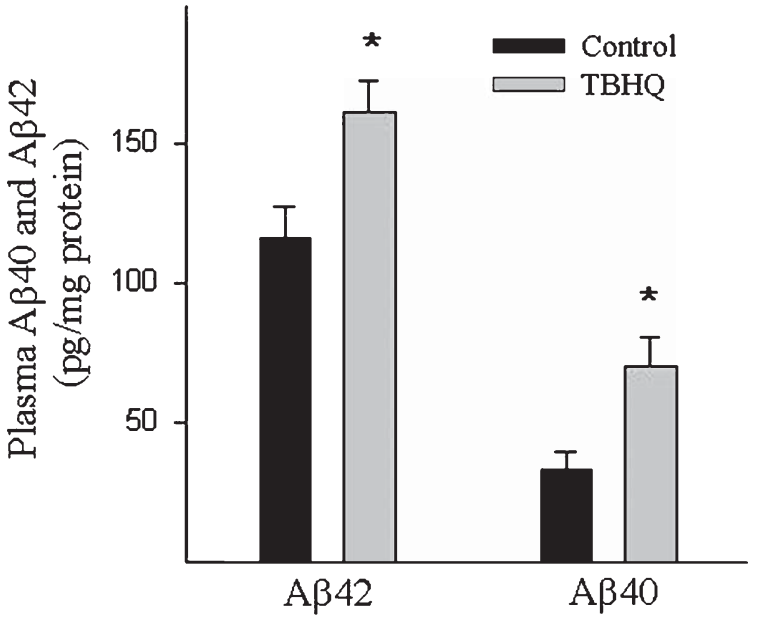

Fig. 5. Effect of TBHQ on plasma $A \beta_{42}$ and $A \beta_{40}$ levels in $\mathrm{A} \beta \mathrm{PP} / \mathrm{PS} 1$ mice. $A \beta_{40}$ and $A \beta_{42}$ levels in the plasma were determined by ELISA. *Significantly different from control diet fed mice $(p<0.05, n=5)$.

$\mathrm{AD}$ is unknown. The levels of $\mathrm{A} \beta$ in the brain represent a dynamic equilibrium state as a result of their biosynthesis, degradation, influx, and efflux. Increasing evidence suggests that decrease in the clearance capacity, including degradation and efflux, may contribute importantly to $A \beta$ accumulation during aging and in AD. Plasminogen activator inhibitor 1 (PAI1) is a primary inhibitor of tissue type and urokinase type of plasminogen activators (tPA and uPA, respectively), which convert plasminogen into plasmin, a serine protease that plays a critical role in $A \beta$ degradation [28-32, 39-41]. It was reported that amyloid deposition in the brain was increased in PAI-1 transgenic mice [42, 43]. Previous studies from this and other laboratories showed, on the other hand, that PAI1 expression was increased in the brain of AD patients and in $\mathrm{A} \beta \mathrm{PP}$ or $\mathrm{A} \beta \mathrm{PP} / \mathrm{PS} 1$ transgenic mice, well established animal models of AD [24, 31, 44, 45]. Knockout of the PAI-1 gene or inhibition of PAI-1 activity with PAI- 1 specific inhibitors reduced brain $A \beta$ burden and reversed cognitive deficits in these $\mathrm{AD}$ model mice [24, 25]. These data strongly suggest that increased PAI-1 expression contributes importantly to the development of amyloidosis in AD. In this study, we further showed that TBHQ administration significantly reduced brain $\mathrm{A} \beta$ load in A $\beta P P / P S 1$ mice, which was associated with an inhibition of PAI-1 expression and increases in the activities of tPA, uPA, and plasmin (Fig. 3). No significant effects of TBHQ on the expression of full length $A \beta P P$ or $\alpha-/ \beta-C T F s$ (Fig. 2). These data further support the notion that PAI-1 plays a pivotal role 
A

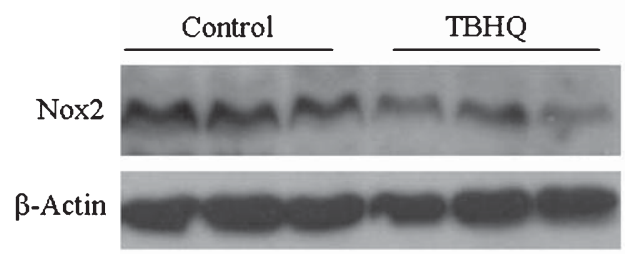

B

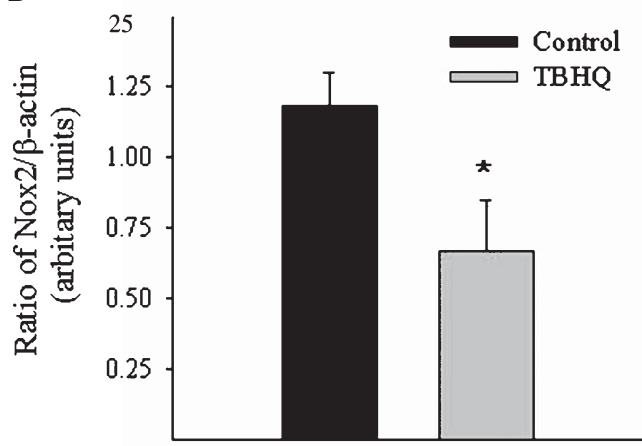

C

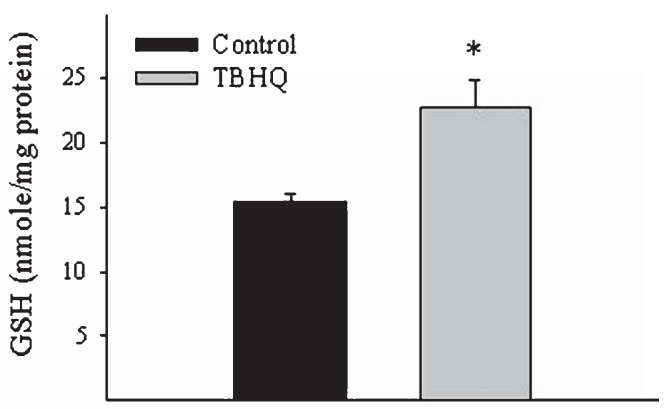

4HNE-modified proteins

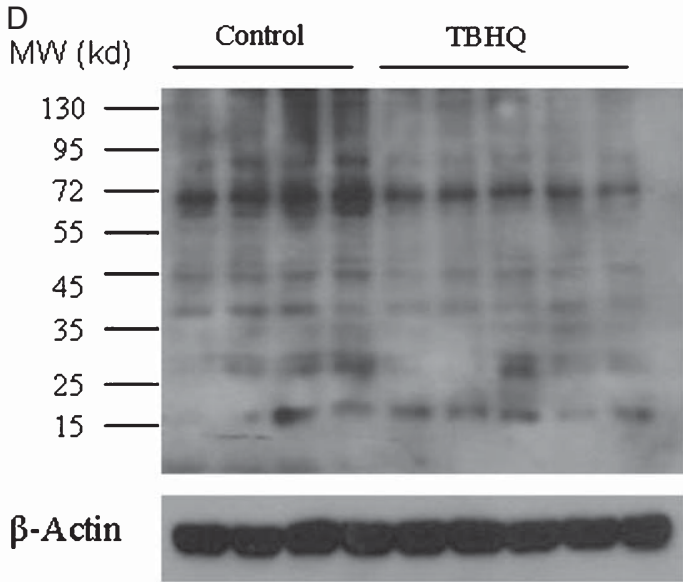

Fig. 6. Effects of TBHQ diet on brain oxidative stress and antioxidant levels in A $\beta P P / P S 1$ mice. A) Representative western blotting picture of Nox 2 protein in the brain of A $\beta P P / P S 1$ transgenic mice. B) Semi-quantitative data of western blotting. *Significantly different from control diet fed A $\beta$ PP/PS1 transgenic mice $(p<0.05, n=5-6)$. C) GSH content in the brain. *Significantly different from control diet fed mice ( $p<0.05$, $n=5-6$ ); D) Representative western blotting picture of 4-HNE modified proteins in the brain of A $\beta P P / P S 1$ mice. $\beta$-actin was used to show equal protein loading between samples.

in AD pathology. These results also suggest that TBHQ reduces brain $A \beta$ load not by inhibiting $A \beta P P / A \beta$ synthesis but, at least in part, by inhibiting PAI-1 expression and thereby stimulating $A \beta$ degradation.

The mechanism underlying the inhibition of PAI-1 expression in the brain of A $\beta P P / P S 1$ mice by TBHQ is unknown at the moment. It has been well documented that oxidative stress is increased with age and in $\mathrm{AD}$. It has also been demonstrated that increased oxidative stress contributes importantly to the pathogenesis of $\mathrm{AD}$, including brain $\mathrm{A} \beta$ accumulation, although the underlying mechanism remains largely undefined. PAI-1 is an early response protein and can be induced by different cytokines/chemokines/gro wth factors including transforming growth factor beta (TGF- $\beta$ ), tumor necrosis factor alpha $(\mathrm{TNF} \alpha)$, and angiotensin II. Interestingly, studies from this and other laboratories have shown that PAI-1 expression is redox regulated and that ROS mediate the induction of PAI-1 by several stimuli in different types of cells [46-52]. The proximal promoter region of the PAI-1 gene contains the binding sites for the activator protein 1 (AP-1), specificity protein 1 (SP-1), and NF-kB, three redox sensitive transcription factors. Our previous studies showed that treatment of fibroblasts with GSH, the most abundance intracellular free thiol and an important antioxidant, or GSH ester blocked the binding of AP-1 and SP-1 to the promoter of the PAI-1 gene and selectively inhibited TGF- $\beta 1$ induced PAI-1 mRNA expression [26, 46, 53]. Our previous studies further showed that, in addition to GSH, NADPH oxidase inhibitor diphenyleneiodonium and superoxide dismutase/catalase mimetic MnTBaP also dramatically reduced TGF- $\beta$-induced PAI- 1 protein expression. Therefore, it was hypothesized that the redox status of cell environment regulates PAI- 


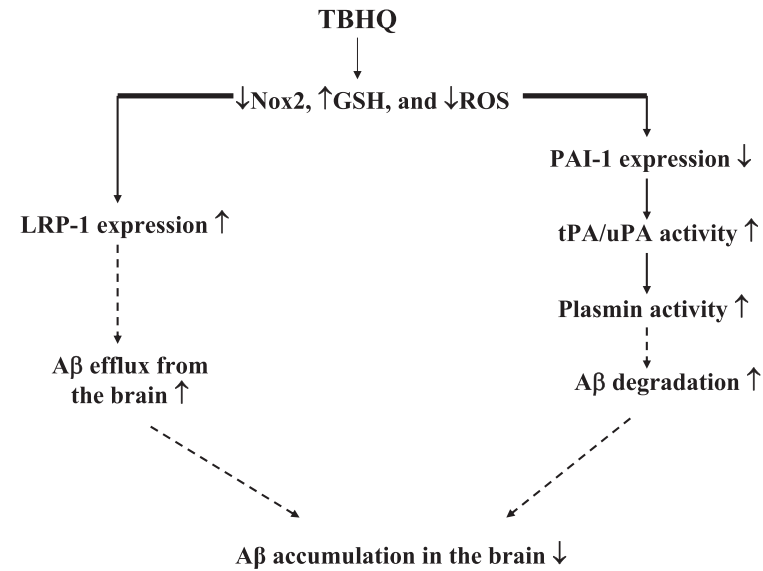

Fig. 7. The hypothetic mechanisms by which TBHQ reduces brain $\mathrm{A} \beta$ load in AD. TBHQ increases antioxidant capacity and reduces oxidative stress levels in the brain, which leads to suppression of the expression of PAI-1, a redox regulated protein, and induction of LRP- 1 and thereby increased $A \beta$ degradation/efflux from the brain. Solid lines represent evidence demonstrated directly from the present study.

1 expression through modulating the binding of the transcription factors AP-1 and SP-1 to the promoter of the PAI-1 gene. Importantly, previous studies from this lab have shown that GSH concentration decreases with age in several organs including the brain in wild type mice and rats as well as in the plasma of $\mathrm{AD}$ patients [54-58]. These data suggest that decrease in GSH level or increase in oxidative stress may underlie the increased PAI-1 expression during aging and in AD. TBHQ can directly scavenge free radicals and also induce the expression of the many enzymes involved in antioxidant defense including glutamate cysteine ligase (GCL), the rate-limiting enzyme in de novo GSH synthesis. In this study, we showed that TBHQ diet increased the concentration of GSH, suppressed the expression of NADPH oxidase 2 (Nox2), and reduced lipid peroxidation level in the brain of A $\beta P P / P S 1$ mice. These results further confirm antioxidant property of TBHQ. These results also suggest that feeding mice with TBHQ diet suppresses PAI-1 gene expression probably by reducing oxidative stress level in the brain.

LRP1 is a multi-function endocytic receptor expressed on endothelium of the BBB, which plays a major role in transporting $A \beta$ out of the brain [33-36]. It has been reported that the expression of LRP-1 at the BBB is decreased in $\mathrm{AD}$, a pre-AD stage referred as amnestic mild cognitive impairment, and in well established animal model of AD, associated with a decreased $A \beta$ efflux and an increased accumulation of $A \beta$ in the brain $[25,37,59-61]$. LRP-
1 expression/activity in the brain is also decreased with increasing age $[25,62]$. Furthermore, it has been reported that LRP-1 antisense selectively decreased LRP-1 expression, reduced BBB clearance of $A \beta_{42}$, increased brain $A \beta_{42}$ level, and impaired learning function in mice [63]. Together, these results suggest that decrease in the expression of LRP-1 during aging and in AD contributes importantly to the pathophysiology of AD. In this study, we showed that TBHQ feeding significantly increased the expression of LRP-1 protein at the $\mathrm{BBB}$, which was accompanied by elevation of plasma $A \beta_{40}$ and $A \beta_{42}$ levels. These data suggest that TBHQ reduces brain A $\beta$ load in A $\beta P P / P S 1$ mice probably also through increasing LRP-1 expression and thereby $A \beta$ efflux from the brain.

The mechanism underlying the decrease in the expression of LRP-1 in the brain during aging and in $\mathrm{AD}$ is unknown. Although there is no published data showing that LRP-1 gene expression is redox regulated, a recent study showed that LRP-1 protein in the hippocampus from $\mathrm{AD}$ patients was oxidatively modified (4-HNE modification) [64]. The authors proposed that $A \beta$ induced oxidative modification of its transporter LRP1, leading to decreased $A \beta$ efflux and increased $A \beta$ deposition in the brain [64]. Whether increased oxidative stress is responsible for the decrease of LRP-1 expression during aging and in $\mathrm{AD}$ and whether TBHQ induces LRP-1 expression by reducing oxidative stress level in the brain of A $3 P P / P S 1$ mice is unknown and warrant further investigation. Understanding the mechanism regulating the expression of LRP-1, a major A $\beta$ transporter from the brain to the blood, may lead to discovery of novel therapeutic agents for this devastating disease.

Overall, the present study demonstrated for the first time that TBHQ administration reduced brain $A \beta$ level in A $\beta P P / P S 1$ mice. The results also suggest that THBQ does so by suppressing oxidative stress and thereby the expression/activity of PAI-1 and by stimulating the expression of LRP-1, which leads to increased degradation/clearance of $A \beta$ from the brain. Together, the results suggest that TBHQ may have therapeutic potential for $\mathrm{AD}$.

\section{ACKNOWLEDGMENTS}

The work was supported by grants from National Institute of Aging (NIA, AG016029) and National Heart, Lung, and Blood Institute (HL088141) to RuiMing Liu (RML); an Award from University of Alabama at Birmingham School of Public Health to 
RML; grants from NIA (AG031846), Alzheimer's Association (IIRG-09-131791), and American Health Assistance Foundation (A2010328) to Ling Li.

Authors' disclosures available online (http://www.jalz.com/disclosures/view.php?id=882).

\section{REFERENCES}

[1] Morgan D, Diamond DM, Gottschall PE, Ugen KE, Dickey C, Hardy J, Duff K, Jantzen P, DiCarlo G, Wilcock D, Connor K, Hatcher J, Hope C, Gordon M, Arendash GW (2000) A[beta] peptide vaccination prevents memory loss in an animal model of Alzheimer's disease. Nature 408, 982-985.

[2] Hock C, Konietzko U, Streffer JR, Tracy J, Signorell A, Müller-Tillmanns B, Lemke U, Henke K, Moritz E, Garcia E, Wollmer MA, Umbricht D, de Quervain DJF, Hofmann M, Maddalena A, Papassotiropoulos A, Nitsch RM (2003) Antibodies against [beta]-Amyloid slow cognitive decline in Alzheimer's disease. Neuron 38, 547-554.

[3] Wilcock DM, Rojiani A, Rosenthal A, Subbarao S, Freeman MJ, Gordon MN, Morgan D (2004) Passive immunotherapy against Abeta in aged APP-transgenic mice reverses cognitive deficits and depletes parenchymal amyloid deposits in spite of increased vascular amyloid and microhemorrhage. $J$ Neuroinflammation 1, 24.

[4] Fukumoto H, Takahashi H, Tarui N, Matsui J, Tomita T, Hirode M, Sagayama M, Maeda R, Kawamoto M, Hirai K, Terauchi J, Sakura Y, Kakihana M, Kato K, Iwatsubo T, Miyamoto M (2010) A noncompetitive BACE1 inhibitor TAK-070 ameliorates $A \beta$ pathology and behavioral deficits in a mouse model of Alzheimer's disease. J Neurosci 30, 11157-11166.

[5] Kimura R, Devi L, Ohno M (2010) Partial reduction of BACE1 improves synaptic plasticity, recent and remote memories in Alzheimer's disease transgenic mice. J Neurochem 113, 248-261.

[6] Fu AL, Dong ZH, Sun MJ (2006) Protective effect of Nacetyl-L-cysteine on amyloid beta-peptide-induced learning and memory deficits in mice. Brain Res 1109, 201-206.

[7] Tucker S, Ahl M, Bush A, Westaway D, Huang X, Rogers JT (2005) Pilot study of the reducing effect on amyloidosis in vivo by three FDA pre-approved drugs via the Alzheimer's APP 5' untranslated region. Curr Alzheimer Res 2, 249-254.

[8] Quinn JF, Bussiere JR, Hammond RS, Montine TJ, Henson E, Jones RE, Stackman RW, Jr (2007) Chronic dietary alphalipoic acid reduces deficits in hippocampal memory of aged Tg2576 mice. Neurobiol Aging 28, 213-225.

[9] Hager K, Kenklies M, McAfoose J, Engel J, Munch G (2007) Alpha-lipoic acid as a new treatment option for Alzheimer's disease-a 48 months follow-up analysis. J Neural Transm Suppl 189-193.

[10] Alamed J, Chaiyasit W, McClements DJ, Decker EA (2009) Relationships between free radical scavenging and antioxidant activity in foods. J Agric Food Chem 57, 29692976.

[11] Liu RM, Shi MM, Giulivi C, Forman HJ (1998) Quinones increase gamma-glutamyl transpeptidase expression by multiple mechanisms in rat lung epithelial cells. Am J Physiol 274, L330-L336.

[12] Liu RM, Hu H, Robison TW, Forman HJ (1996) Differential enhancement of gamma-glutamyl transpeptidase and gamma- glutamylcysteine synthetase by tert-butylhydroquinone in rat lung epithelial L2 cells. Am J Respir Cell Mol Biol 14, 186191.

[13] Liu RM, Hu H, Robison TW, Forman HJ (1996) Increased gamma-glutamylcysteine synthetase and gamma-glutamyl transpeptidase activities enhance resistance of rat lung epithelial L2 cells to quinone toxicity. Am J Respir Cell Mol Biol 14, 192-197.

[14] Li J, Johnson D, Calkins M, Wright L, Svendsen C, Johnson J (2005) Stabilization of Nrf2 by tBHQ confers protection against oxidative stress-induced cell death in human neural stem cells. Toxicol Sci 83, 313-328.

[15] Shih AY, Li P, Murphy TH (2005) A small-molecule-inducible Nrf2-mediated antioxidant response provides effective prophylaxis against cerebral ischemia in vivo. J Neurosci $\mathbf{2 5}$, 10321-10335.

[16] Duvoix A, Schnekenburger M, Delhalle S, Blasius R, Borde-Chiché P, Morceau F, Dicato M, Diederich M (2004) Expression of glutathione S-transferase P1-1 in leukemic cells is regulated by inducible AP-1 binding. Cancer Lett 216, 207-219.

[17] Prince M, Li Y, Childers A, Itoh K, Yamamoto M, Kleiner HE (2009) Comparison of citrus coumarins on carcinogendetoxifying enzymes in Nrf2 knockout mice. Toxicol Lett 185 , 180-186.

[18] Kraft AD, Johnson DA, Johnson JA (2004) Nuclear factor E2-related factor 2-dependent antioxidant response element activation by tert-butylhydroquinone and sulforaphane occurring preferentially in astrocytes conditions neurons against oxidative insult. $J$ Neurosci $\mathbf{2 4}$, 1101-1112.

[19] Abdel-Wahab MH (2005) Potential neuroprotective effect of t-butylhydroquinone against neurotoxicity-induced by 1 methyl-4-(2'-methylphenyl)-1,2,3,6-tetrahydropyridine (2'methyl-MPTP) in mice. J Biochem Mol Toxicol 19, 32-41.

[20] Shih AY, Imbeault S, Barakauskas V, Erb H, Jiang L, Li P, Murphy TH (2005) Induction of the Nrf2-driven antioxidant response confers neuroprotection during mitochondrial stress in vivo. J Biol Chem 280, 22925-22936.

[21] Shah ZA, Li RC, Thimmulappa RK, Kensler TW, Yamamoto M, Biswal S, Dore S (2007) Role of reactive oxygen species in modulation of Nrf2 following ischemic reperfusion injury. Neuroscience 147, 53-59.

[22] Liu XY, Li CY, Bu H, Li Z, Li B, Sun MM, Guo YS, Zhang L, Ren WB, Fan ZL, Wu DX, Wu SY (2008) The neuroprotective potential of phase II enzyme inducer on motor neuron survival in traumatic spinal cord injury in vitro. Cell Mol Neurobiol 28, 769-779.

[23] Siebert A, Desai V, Chandrasekaran K, Fiskum G, Jafri MS (2009) Nrf2 activators provide neuroprotection against 6hydroxydopamine toxicity in rat organotypic nigrostriatal cocultures. J Neurosci Res 87, 1659-1669.

[24] Liu RM, van Groen T, Katre A, Cao D, Kadisha I, Ballinger C, Wang L, Carroll SL, Li L (2011) Knockout of plasminogen activator inhibitor 1 gene reduces amyloid beta peptide burden in a mouse model of Alzheimer's disease. Neurobiol Aging 32, 1079-1089.

[25] Shibata M, Yamada S, Kumar SR, Calero M, Bading J, Frangione B, Holtzman DM, Miller CA, Strickland DK, Ghiso J, Zlokovic BV (2000) Clearance of Alzheimer's amyloid-ss (1-40) peptide from brain by LDL receptor-related protein-1 at the blood-brain barrier. J Clin Invest 106, 14891499.

[26] Vayalil PK, Olman M, Murphy-Ullrich JE, Postlethwait EM, Liu RM (2005) Glutathione restores collagen degradation in 
TGF-beta-treated fibroblasts by blocking plasminogen activator inhibitor-1 expression and activating plasminogen. Am J Physiol Lung Cell Mol Physiol 289, L937-L945.

[27] Beutler E (1969) Effect of flavin compounds on glutathione reductase activity: In vivo and in vitro studies. J Clin Invest 48, 1957-1966.

[28] Van Nostrand WE, Porter M (1999) Plasmin cleavage of the amyloid beta-protein: Alteration of secondary structure and stimulation of tissue plasminogen activator activity. Biochemistry 38, 11570-11576.

[29] Periz G, Fortini ME (2000) Proteolysis in Alzheimer's disease. Can plasmin tip the balance? EMBO Rep 1, 477-478.

[30] Ledesma MD, Da Silva JS, Crassaerts K, Delacourte A, De Strooper B, Dotti CG (2000) Brain plasmin enhances APP alpha-cleavage and Abeta degradation and is reduced in Alzheimer's disease brains. EMBO Rep 1, 530-535.

[31] Melchor JP, Pawlak R, Strickland S (2003) The tissue plasminogen activator-plasminogen proteolytic cascade accelerates amyloid-beta (Abeta) degradation and inhibits Abeta-induced neurodegeneration. J Neurosci 23, 8867-8871.

[32] Exley C, Korchazhkina OV (2001) Plasmin cleaves Abeta42 in vitro and prevents its aggregation into beta-pleated sheet structures. Neuroreport 12, 2967-2970.

[33] Deane R, Bell RD, Sagare A, Zlokovic BV (2009) Clearance of amyloid-beta peptide across the blood-brain barrier: Implication for therapies in Alzheimer's disease. CNS Neurol Disord Drug Targets 8, 16-30.

[34] Zlokovic BV (2008) New therapeutic targets in the neurovascular pathway in Alzheimer's disease. Neurotherapeutics 5, 409-414.

[35] Bell RD, Sagare AP, Friedman AE, Bedi GS, Holtzman DM, Deane R, Zlokovic BV (2007) Transport pathways for clearance of human Alzheimer's amyloid beta-peptide and apolipoproteins $\mathrm{E}$ and $\mathrm{J}$ in the mouse central nervous system. J Cereb Blood Flow Metab 27, 909-918.

[36] Bates KA, Verdile G, Li QX, Ames D, Hudson P, Masters CL, Martins RN (2009) Clearance mechanisms of Alzheimer's amyloid-beta peptide: Implications for therapeutic design and diagnostic tests. Mol Psychiatry 14, 469-486.

[37] Kang DE, Pietrzik CU, Baum L, Chevallier N, Merriam $\mathrm{DE}$, Kounnas MZ, Wagner SL, Troncoso JC, Kawas CH, Katzman R, Koo EH (2000) Modulation of amyloid betaprotein clearance and Alzheimer's disease susceptibility by the LDL receptor-related protein pathway. J Clin Invest $\mathbf{1 0 6}$, 1159-1166.

[38] Aderinwale OG, Ernst HW, Mousa SA (2010) Current therapies and new strategies for the management of Alzheimer's disease. Am J Alzheimers Dis Other Demen 25, 414-424.

[39] Tucker HM, Kihiko M, Caldwell JN, Wright S, Kawarabayashi T, Price D, Walker D, Scheff S, McGillis JP, Rydel RE, Estus S (2000) The plasmin system is induced by and degrades amyloid-beta aggregates. J Neurosci 20, 3937-3946.

[40] Melchor JP, Pawlak R, Chen Z, Strickland S (2003) The possible role of tissue-type plasminogen activator (tPA) and tPA blockers in the pathogenesis and treatment of Alzheimer's disease. J Mol Neurosci 20, 287-289.

[41] Turner AJ, Nalivaeva NN (2007) New insights into the roles of metalloproteinases in neurodegeneration and neuroprotection. Int Rev Neurobiol 82, 113-135.

[42] Eren M, Gleaves LA, Atkinson JB, King LE, Declerck PJ, Vaughan DE (2007) Reactive site-dependent phenotypic alterations in plasminogen activator inhibitor-1 transgenic mice. $J$ Thromb Haemost 5, 1500-1508.
[43] Vaughan DE, De Taeye BM, Eren M (2007) PAI-1 antagonists: Predictable indications and unconventional applications. Curr Drug Targets 8, 962-970.

[44] Cacquevel M, Launay S, Castel H, Benchenane K, Cheenne S, Buee L, Moons L, Delacourte A, Carmeliet P, Vivien D (2007) Ageing and amyloid-beta peptide deposition contribute to an impaired brain tissue plasminogen activator activity by different mechanisms. Neurobiol Dis 27, 164-173.

[45] Jacobsen JS, Comery TA, Martone RL, Elokdah H, Crandall DL, Oganesian A, Aschmies S, Kirksey Y, Gonzales C, Xu J, Zhou H, Atchison K, Wagner E, Zaleska MM, Das I, Arias RL, Bard J, Riddell D, Gardell SJ, Abou-Gharbia M, Robichaud A, Magolda R, Vlasuk GP, Bjornsson T, Reinhart PH, Pangalos MN (2008) Enhanced clearance of Abeta in brain by sustaining the plasmin proteolysis cascade. Proc Natl Acad Sci U S A 105, 8754-8759.

[46] Vayalil PK, Iles KE, Choi J, Yi A-K, Postlethwait EM, Liu R-M (2007) Glutathione suppresses TGF-beta-induced PAI-1 expression by inhibiting $\mathrm{p} 38$ and JNK MAPK and the binding of AP-1, SP-1, and Smad to the PAI-1 promoter. Am J Physiol Lung Cell Mol Physiol 293, L1281-L1292.

[47] Liu RM, Choi J, Wu JH, Gaston Pravia KA, Lewis KM, Brand JD, Mochel NS, Krzywanski DM, Lambeth JD, Hagood JS, Forman HJ, Thannickal VJ, Postlethwait EM (2010) Oxidative modification of nuclear mitogen-activated protein kinase phosphatase 1 is involved in transforming growth factor beta1induced expression of plasminogen activator inhibitor 1 in fibroblasts. J Biol Chem 285, 16239-16247.

[48] Jiang Z, Seo JY, Ha H, Lee EA, Kim YS, Han DC, Uh ST, Park CS, Lee HB (2003) Reactive oxygen species mediate TGFbeta1-induced plasminogen activator inhibitor-1 upregulation in mesangial cells. Biochem Biophys Res Commun 309, 961966.

[49] Uchida Y, Ohba K, Yoshioka T, Irie K, Muraki T, Maru Y (2004) Cellular carbonyl stress enhances the expression of plasminogen activator inhibitor-1 in rat white adipocytes via reactive oxygen species-dependent pathway. J Biol Chem $\mathbf{2 7 9}$, 4075-4083.

[50] Hong HK, Song CY, Kim BC, Lee HS (2006) ERK contributes to the effects of Smad signaling on oxidized LDL-induced PAI-1 expression in human mesangial cells. Transl Res 148, 171-179.

[51] Vulin AI, Stanley FM (2004) Oxidative stress activates the plasminogen activator inhibitor type 1 (PAI-1) promoter through an AP-1 response element and cooperates with insulin for additive effects on PAI-1 transcription. J Biol Chem 279, 25172-25178.

[52] Du XL, Edelstein D, Rossetti L, Fantus IG, Goldberg H, Ziyadeh F, Wu J, Brownlee M (2000) Hyperglycemiainduced mitochondrial superoxide overproduction activates the hexosamine pathway and induces plasminogen activator inhibitor-1 expression by increasing Sp1 glycosylation. Proc Natl Acad Sci U S A 97, 12222-12226.

[53] Liu R-M, Liu Y, Forman HJ, Olman M, Tarpey MM (2004) Glutathione regulates transforming growth factorbeta-stimulated collagen production in fibroblasts. Am J Physiol Lung Cell Mol Physiol 286, L121-L128.

[54] Liu R-M, Choi J (2000) Age-associated decline of gammaglutamylcysteine synthetase gene expression in rats. Free Radic Biol Med 28, 566-574.

[55] Liu RM (2002) Down-Regulation of gamma-Glutamylcysteine Synthetase Regulatory Subunit Gene Expression in Rat Brain Tissue During Aging. J Neurosci Res 68, 344-351. 
[56] Liu RM, Dickinson DA (2003) Decreased synthetic capacity underlies the age-associated decline in glutathione content in Fisher 344 rats. Antioxid Redox Signal 5, 529-536.

[57] Liu H, Wang H, Shenvi S, Hagen TM, Liu R-M (2004) Glutathione Metabolism during Aging and in Alzheimer Disease. Ann NY Acad Sci 1019, 346-349.

[58] Liu H, Harrell LE, Shenvi S, Hagen T, Liu RM (2005) Gender differences in glutathione metabolism in Alzheimer's disease. J Neurosci Res 79, 861-867.

[59] Donahue JE, Flaherty SL, Johanson CE, Duncan JA, 3rd, Silverberg GD, Miller MC, Tavares R, Yang W, Wu Q, Sabo E, Hovanesian V, Stopa EG (2006) RAGE, LRP-1, and amyloidbeta protein in Alzheimer's disease. Acta Neuropathol 112, 405-415.

[60] Deane R, Wu Z, Sagare A, Davis J, Du Yan S, Hamm K, Xu F, Parisi M, LaRue B, Hu HW, Spijkers P, Guo H, Song X, Lenting PJ, Van Nostrand WE, Zlokovic BV (2004) LRP/amyloid beta-peptide interaction mediates differential brain efflux of Abeta isoforms. Neuron 43, 333-344.

[61] Sultana R, Banks WA, Butterfield DA (2010) Decreased levels of PSD95 and two associated proteins and increased levels of $\mathrm{BCl} 2$ and caspase 3 in hippocampus from subjects with amnestic mild cognitive impairment: Insights into their potential roles for loss of synapses and memory, accumulation of Abeta, and neurodegeneration in a prodromal stage of Alzheimer's disease. J Neurosci Res 88, 469-477.

[62] Bading JR, Yamada S, Mackic JB, Kirkman L, Miller C, Calero M, Ghiso J, Frangione B, Zlokovic BV (2002) Brain clearance of Alzheimer's amyloid-beta40 in the squirrel monkey: a SPECT study in a primate model of cerebral amyloid angiopathy. J Drug Target 10, 359-368.

[63] Jaeger LB, Dohgu S, Hwang MC, Farr SA, Murphy MP, Fleegal-DeMotta MA, Lynch JL, Robinson SM, Niehoff ML, Johnson SN, Kumar VB, Banks WA (2009) Testing the neurovascular hypothesis of Alzheimer's disease: LRP1 antisense reduces blood-brain barrier clearance, increases brain levels of amyloid-beta protein, and impairs cognition. $J$ Alzheimers Dis 17, 553-570.

[64] Owen JB, Sultana R, Aluise CD, Erickson MA, Price TO, Bu G, Banks WA, Butterfield DA (2010) Oxidative modification to LDL receptor-related protein 1 in hippocampus from subjects with Alzheimer disease: Implications for Abeta accumulation in AD brain. Free Radic Biol Med 49, 1798-1803. 